\title{
First description of Benibotarus Kôno, 1932 larva, with supplementary data on B. longicornis (Reiche, 1878) imago (Coleoptera: Lycidae)
}

\section{Первоописание мичинки рода Benibotarus Kôno, 1932, с дополнительными данными по имаго B. longicornis (Reiche, 1878) (Coleoptera: Lycidae)}

\author{
Sergey V. Kazantsev ${ }^{1}$, Artjom A. Zaitsev ${ }^{2}$ \\ С.В. Казанцев ${ }^{1}$, А.А. Зайџев ${ }^{2}$

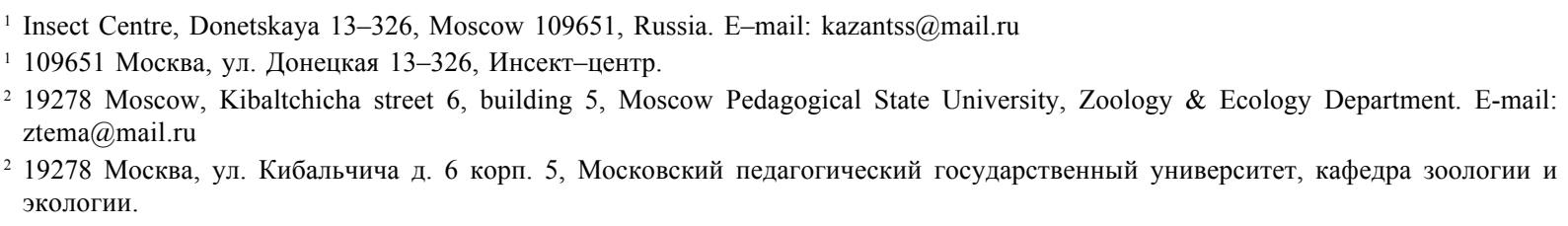

KEY WORDS: Coleoptera, Lycidae, larvae, Palaearctic region.

КЛЮЧЕВЫЕ СЛОВА: Coleoptera, Lycidae, личинки, Палеарктическая область.

ABSTRACT. A larva of Benibotarus longicornis (Reiche, 1878) from the western Caucasus is described for the first time, this being also the first description of a larva in the dictyopterine genus Benibotarus Kôno, 1932. A female of B. longicornis is also described for the first time, and both a male and a female of the species are illustrated by macrophotographs.

РЕЗЮМЕ. Приводится первоописание личинки Benibotarus longicornis (Reiche, 1878) с Западного Кавказа, что является одновременно и первым описанием личинки в роде Benibotarus Kôno, 1932 трибы Dictyopterini. Также приводится первоописание самки B. longicornis, наряду с макрофоторафиями как самки, так и самца этого вида.

\section{Introduction}

The genus Benibotarus Kôno, 1932 of the net-winged beetles tribe Dictyopterini is distributed in a vast area from northwestern Africa and southwestern Europe to Japan and Taiwan, but its six species are restricted in majority of cases to small territories, separated from each other by considerable distance [Bocakova, Bocak, 2007]. In the Caucasus, for example, there are two Benibotarus species, one in the west and the other in the southeast.

One of the Caucasian species, Benibotarus longicornis (Reiche, 1878), from the west of the region, was initially described in Eros Newman, 1838 [Reiche, 1878], then the species was moved to Dictyoptera Latreille, 1929 [Jacobson, 1911; Barovskij, 1931; Kleine, 1942] until it was finally accommodated in Benibotarus [Bocak, Bocakova, 1987; Bocakova, Bocak, 2007; Kazantsev, 2004; 2012]. In the meanwhile the same species was introduced as Pyropterus Mulsant, 1838 [Barovskij, 1930] and later synonymized [Kazantsev, 1990].

The present study is a further contribution to the knowledge of Benibotarus and B. longicornis. During the fieldwork in the Caucasus Nature Reserve several lycid larvae were found by one of the authors that, apparently belonging to dictyopterines, did not quite fit into Dictyoptera or Pyropterus, the only Dictyopterini genera known to occur in this part of the Palaearctic realm, in addition to Benibotarus. Besides, neither Dictyoptera nor Pyropterus have been signalled for the Northwestern Caucasus, and for the Caucasus in general [Bocakova, Bocak, 2007; Kazantsev, 2011]. On the other hand, adults of B. longicornis have been reported to the north and to the south of the larval collecting site (Map 1), and it was only natural to presume that these were nothing else, but larvae of B. longicornis. Description of this larva is presented below. As no preimaginal stages were known in this genus [Kazantsev, Nikitsky, 2011], that would also be the first description of a Benibotarus larva. The female of $B$. longicornis from the Fursov collection deposited at the Zoological Museum of Moscow University is also described for the first time.

How to cite this article: Kazantsev S.V., Zaitsev A.A. 2021. First description of Benibotarus Kôno, 1932 larva, with supplementary data on B. longicornis (Reiche, 1878) imago (Coleoptera: Lycidae) // Russian Entomol. J. Vol.30. No.3. P.275-281. doi: 10.15298/rusentj.30.3.04 


\section{Material and Methods}

The studied adult specimens were pinned. For examination the beetles were relaxed in water, then their detached abdomina were kept for several hours in $10 \% \mathrm{KOH}$ at room temperature. The $\mathrm{KOH}$ treated aedeagi and terminal abdominal segments were then placed in microvials with glycerin for photographing. The larvae were preserved and photographed in $70 \%$ alcohol.

MSP-1 zoom stereoscopic dissecting microscope with $\times 8-\times 80$ and Micromed-2/3-20 zoom stereoscopic light microscope with $\times 100-\times 400$ magnification range were used. Photographs were taken with Canon EOS 6D and Canon EOS 40D cameras with a MP-E $65 \mathrm{~mm}$ macro lens, as well as a Canon EOS 6D camera attached to a Carl Zeiss AXIO Scope.A1 microscope. All photographs of larvae were processed using Helicon Focus software.

The following acronyms are used in the paper: ICM Insect Center, Moscow; MPGU - Moscow Pedagogical State University, Moscow; ZIN - Zoological Institute, St.Petersburg; ZMMU — Zoological Museum of Moscow University.

\section{Taxonomy}

\section{Dictyopterini \\ Benibotarus Kôno, 1932}

Benibotarus Kôno, 1932: 56.

Type species: Eros spinicoxis Kiesenwetter, 1874 (original designation).

DISTRIBUTION. The distribution pattern of Benibotarus is distinctly disjunctive, the distribution areas of its six species scattered from the west of North Africa and Iberian Peninsula to Japan and Taiwan. Its six rare species have been registered in the Rif Mountains (1 species), the Iberian Peninsula (1 species), southern Europe (1 species), the Caucasus (2 species), and across relatively vast territory in the Far East: Russian Maritime Territory, Japan, South Korea, northeastern China and Taiwan (1 species). One of the Caucasian species, Benibotarus longicornis, is the rarest of the six, and is known only by four adult specimens, the most recent collecting dating back to 1931 .

DIAGNOSIS. Adults of Benibotarus differ from other dictyopterine genera in the reduction of elytral costa 2 , combined with relatively equal stoutness of the remaining three primary elytral costae and relative shortness of hind trochanters [Kazantsev, 2004]. The larva of Benibotarus longicornis, being quite similar to Pyropterus Mulsant, 1838, is separable by the distinctly less transverse tergite 9 (ca. 1.2 times wider than long), which is divided medially by a concolourous with the tergite disk suture, by the location of abdominal spiracles that are far from the dorsal edge of the epipleurite, and greater size of the spiracle of abdominal segment 1 compared to the spiracles of segments 2-7. In contrast, in Pyropterus tergite 9 is conspicuously transverse (ca. 2 times wider than long), divided medially by light suture; its abdominal spiracles are located at the dorsal edge of epipleurite, and the spiracle of abdominal segment 1 does not noticeably surpass in size those of the spiracles of segments 2-7 [Kazantsev, Nikitsky, 2011]. On the other hand, the Benibotarus larva is easily distinguishable from Dictyoptera by the non-fused with lateral sclerites cranium and divided tergite 9, whereas the Dictyoptera larva is characterised by the cranium fused with lateral sclerites and undivided tergite 9 [Kazantsev, Nikitsky, 2011].
BIOLOGY. The larvae of Benibotarus longicornis were collected under loose bark of a fallen fir at ca. $1200 \mathrm{~m}$ above level.

\section{Benibotarus longicornis (Reiche, 1878)} Figs $1-18$

Eros longicornis Reiche, 1878: XXVII.

Dictyoptera longicornis: Jacobson, 1911: 666; Barovskij, 1931: 15; Kleine, 1942: 49

Benibotarus longicornis: Bocak et Bocakova, 1987: 116

= Pyropterus shelkovnikovi Barovskij, 1930: 615; 1931: 21; Kleine, 1942: 44

MATERIAL: Larvae: 3 specimens, S Russia, NW Caucasus, Adygeya, Guzeripl, env. Mt. Filimonova, under bark of dead fur, $1200 \mathrm{~m}, 43.9981 \mathrm{~N}, 40.1695 \mathrm{E}, 15 . \mathrm{VI} .2007$, A. Zaitsev leg. (ICM and MPGU); imago: + , [Russia], 'Eisk. m., Mnk.1., 31.X.(19)10' (ZMMU, Fig. 18); $\sigma^{7}$, 'Caucasus, [Georgia], Distr. Gori, Bakuriani, [6000 feet], 20.VIII.1912, [M. Kozlovskij]' , 'Pyropterus shelkovnikovi typ. un.' (Barovskij's manuscript label) (ZIN); O', [Abkhasia], 'Sukhum, Mt. Bograt, park Vira, 3.XII.1931, B. Roddendorf' (ICM).

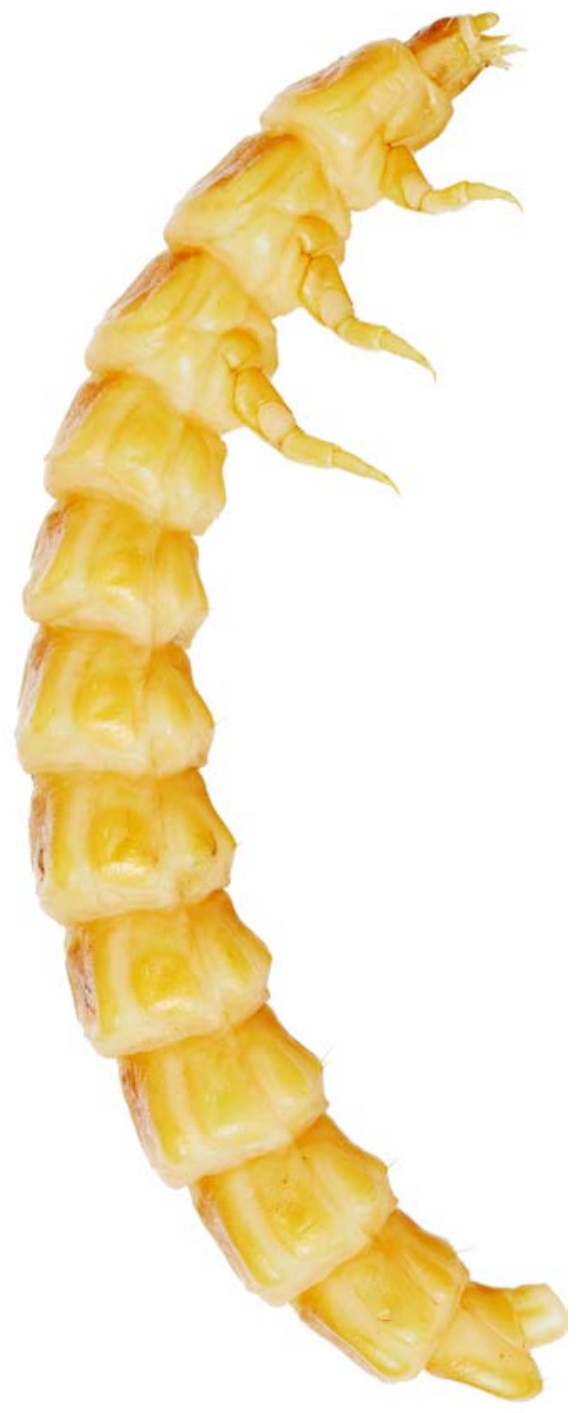

Fig. 1. General view of Benibotarus longicornis, last (?) instar. Рис. 1. Общий вид Benibotarus longicornis, личинка последнего (?) возраста. 
DESCRIPTION. Last (?) instar. Body elongate, almost parallel-sided in thoracic and abdominal segments I-V, flattened. Upperside light yellow, with brownish spots at disk; head dorsally brownish; sclerites of underside and legs light yellow; cuticle uniformly finely alveolate (Figs 1-7).

Head strongly transverse, dorsally with convex anterior margin; head capsule open ventrally; lateral sclerites not fused to cranium, but approximate anteriorly, with two anterior setae; cranium (dorsal plate) with a pair of broadly separated setae at anterior margin, a pair of large setae at disk and a pair of setae at anterior-lateral corners; ventral plates with two anterior setae near lateral margin. Stemmata absent. Antennae located antero-laterally, relatively small, retractable, one-segmented, scapus elongate, ca. 1.5 times longer
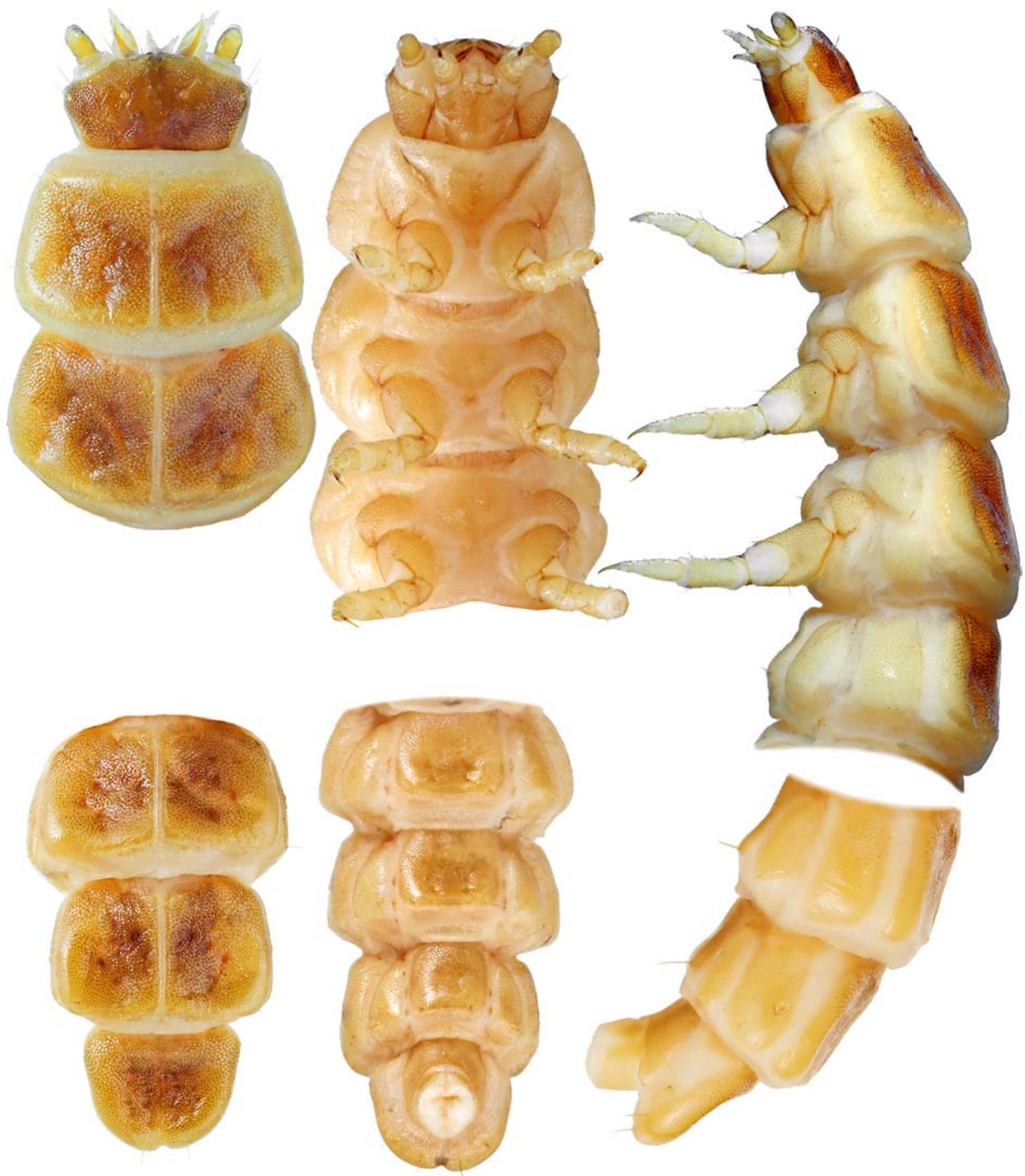

Figs 2-7. Details of Benibotarus longicornis, last (?) instar: 2 - head and first two thoracic segments; 3 - head and thoracic segments; 4 - anterior part of body; 5 - abdominal segments $7-9 ; 6$ - abdominal segments $6-10 ; 7$ - abdominal segments $7-10 ; 2,5-$ dorsally; 3,6 - ventrally; 4, 7 - laterally.

Рис. 2-7. Детали строения Benibotarus longicornis, личинка последнего (?) возраста: 2 - голова и два передних грудных сегмента; 3 - голова и грудные сегменты; 4 - передняя часть тела; 5 - брюшные сегменты 7-9; 6 - брюшные сегменты 6-10; 7 - брюшные сегменты 7-10; 2, 5- сверху; 3, 6- снизу; 4, 7 - сбоку. 
than wide; antennifer represented by narrow annuliform sclerite; scapus with relatively small apical membranous bilobed slit and two short distal setae (Figs 8-10).

Mandibular structures tripartite, consisting of sheath (ventral part), stiletto (narrow central part) and shutter (dorsal part). Sheath narrow, free; stiletto very narrow, distally attached to shutter; shutter one-segmented, narrow, with prominent seta near base; sheath/shutter (fossa/condyle) joint near the base of mandible (Figs 9-10).

Maxillary stipites fused to each other, forming ventral plate, with a pair of setae at antero-lateral corner and two setae at anterior margin. Galea elongate, almost attaining to apex of palpomere 2, basally fused with palpiger, located, with respect to palps, intero-dorsally, with several setae. Palps threesegmented; palpiger well developed, transverse, ca. 1.5 times longer than wide, subequal in length to palpomeres 1 and 2 taken together, with numerous apical and lateral setae; palpomeres 1 and 2 of approximately equal length and width, but palpomere 1 noticeably wider than palpomere 2; palpomere 3 conspicuously narrower than palpomere 2 and subequal in length to palpomere 1. Labial prementum narrow, not divided by median suture; palps two-segmented; ligula absent (Fig. 10).
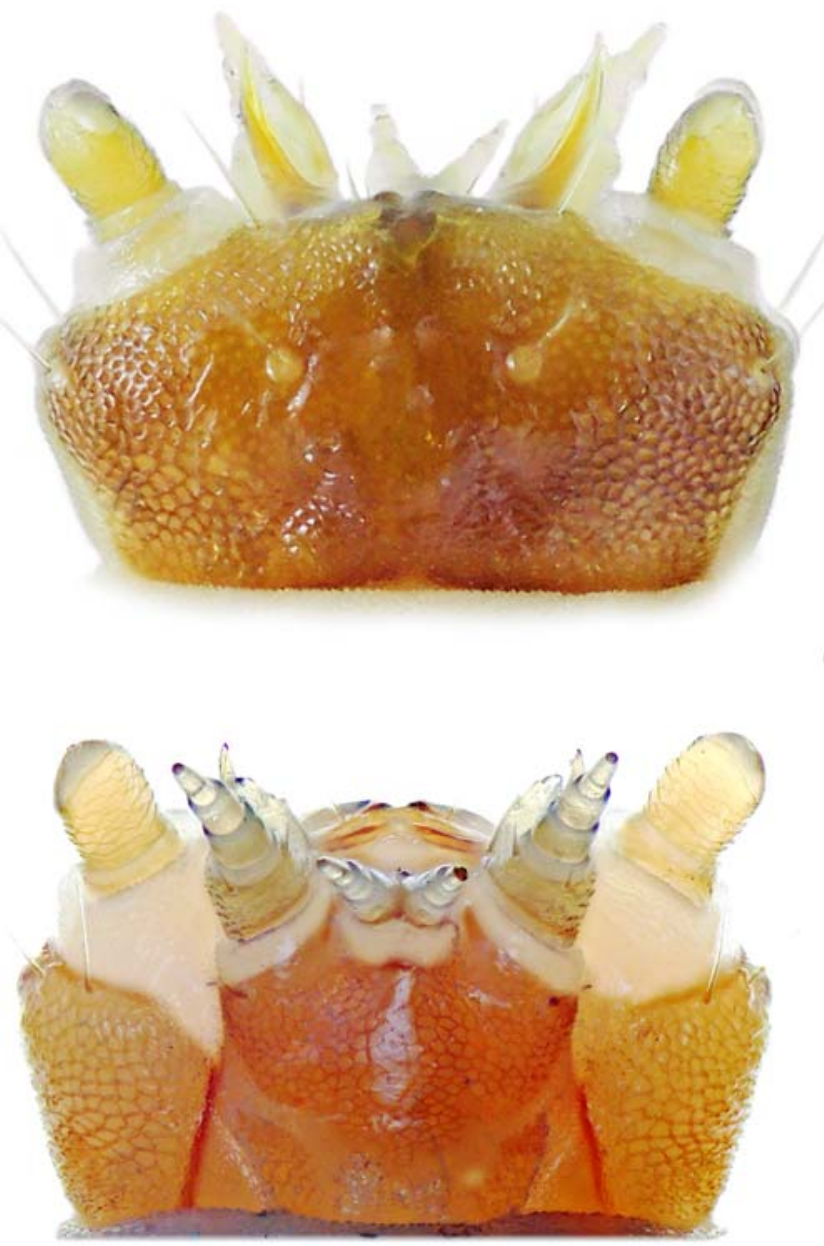

Thoracic terga not wider than abdominal tergites, with transverse sclerites, divided medially into two parts by a conspicuous light suture (Fig. 1). Thoracic pleura consisting of two sclerites, roundish anterior epipleurite and slightly more elongate posterior hypopleurite; in prothorax epipleurite absent, hypopleurite semi-fused to tergum. Mesothoracic epipleurite with relatively large, annular-biforous functional spiracle; metathoracic epipleurite with minute non-functional spiracle (Fig. 4). Sclerites of sterna heart-shaped, with two relatively short discal setae (Fig. 3).

Coxa elongate; trochanter divided by a narrow membranous/less sclerotised stripe into two parts. Coxa, trochanter and femur with two relatively long setae each; tibia with numerous short setae. Tibiae of front legs subequal in length to femurs, tibiae of middle and hind legs slightly longer than femurs. Claws elongate, but considerably shorter than tibiae, with one prominent seta on conspicuously widened basis at inner margin and another at outer margin at the base (Figs 3-4).

Sclerites of abdominal tergites 1-8 transverse, subrectangular, with rounded corners, divided medially into two parts by a conspicuous light suture. Tergite 9 moderately transverse, ca. 1.2 times wider than long, with rounded posterior margin, slightly notched medially, divided medially by incon-

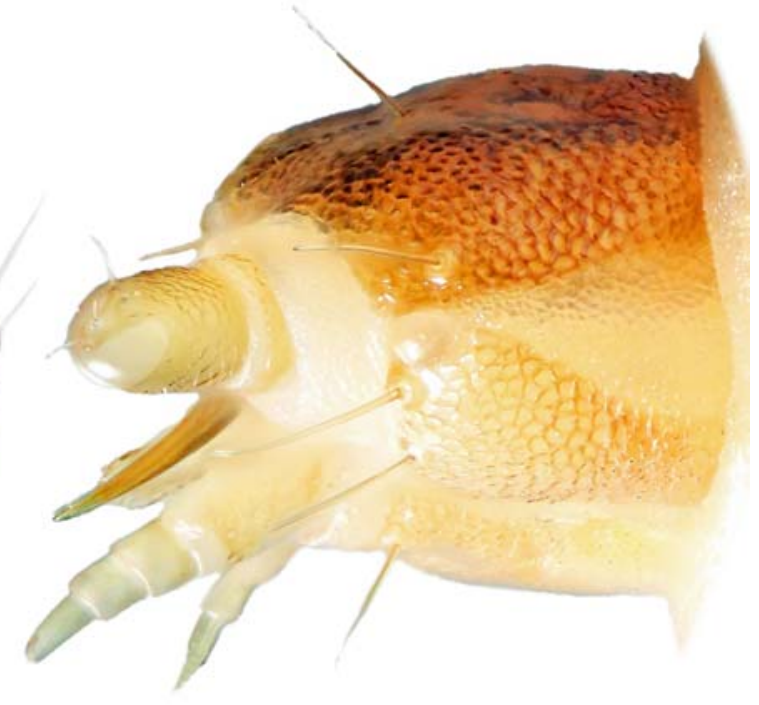

Figs 8-11. Details of Benibotarus longicornis, last (?) instar: 8-10 - head; 11 - abdominal segment 9; 8, 11 - dorsally; 9 - laterally; 10 - ventrally.

Рис. 8-11. Детали строения Benibotarus longicornis, личинка последнего (?) возраста: 8-10 — голова; 11 - брюшной сегмент 9; 8, 11 - сверху; 9 - сбоку; 10- снизу. 
spicuous suture, concolourous with the tergite disk, with six setae at posterior edge, two dorsally and four ventrally. Abdominal pleura consisting of two elongate sclerites, larger epipleurite (more dorsal) and smaller sternopleurite (more ventral). Abdominal spiracles, present in segments $1-8$, annular-biforous, located in the centre of dorsal half, far from dorsal edge of epipleurite; abdominal spiracle of segment 1 relatively large, similar to mesothoracic spiracle, abdominal spiracles of segments 2-7 small. Sclerites of sternites transverse, subrectangular, with slightly rounded corners and a pair of setae at posterior margin. Abdominal segment 10 tubular, ca. 1.3 times shorter than long (Figs 5-7, 11).

Length: $9.5 \mathrm{~mm}$; width (at dorsum): $1.7 \mathrm{~mm}$.

Female. Dark brown to black; pronotum and elytra bright red; scutellum reddish brown at apex (Fig. 16).

Vertex with shallow impression behind antennal prominence and a pair of small round excavations at it bottom. Eyes small, interocular distance ca. 2.3 times greater than eye diameter. Labrum small, transverse, convex anteriorly. Palps relatively robust; ultimate palpomeres about as long as wide, obliquely convex at apex. Antennal sockets separated by narrow lamina. Antennae attaining to elytral middle, filiform; antennomere 3 subequal in length to antennomere 2, but noticeably wider, and ca. 3 times shorter than antennomere 4; antennomeres 3-11 with short sub-erect pubescence (Figs 16, 17).

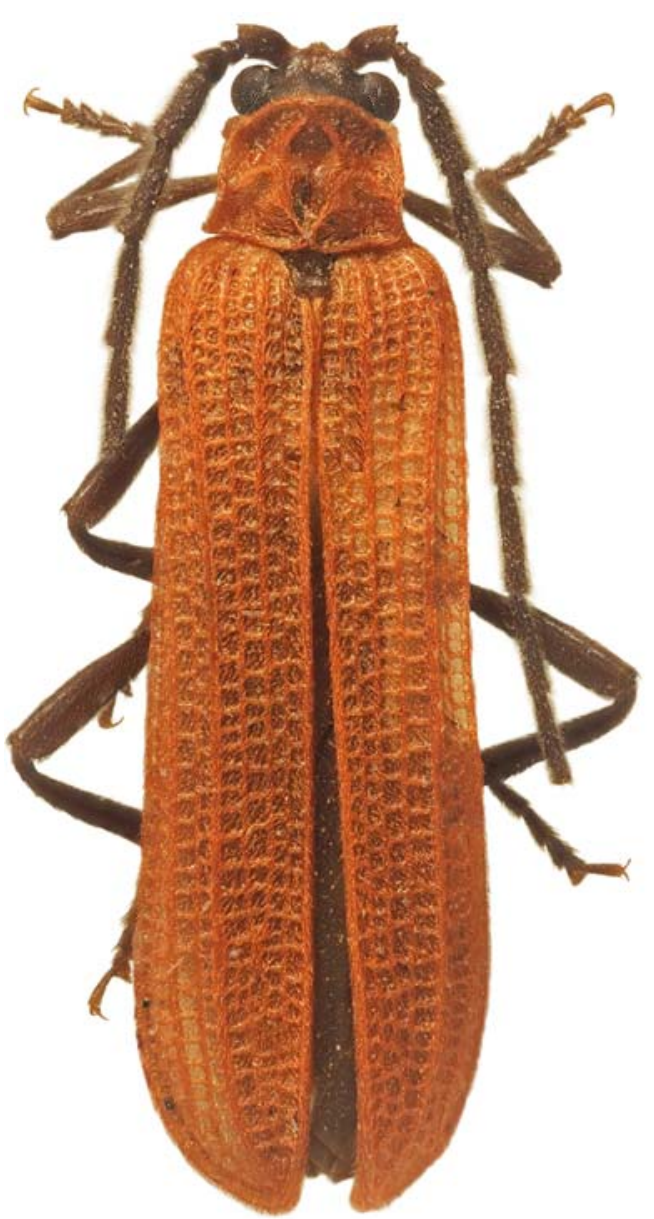

Pronotum transverse, ca. 1.5 times wider than long, with straight sides, sinuate basally and noticeably produced anteriorly, with small acute posterior and distinct anterior angles; median cell broad, oval, not attaining to posterior margin. Scutellum triangular, slightly widened before and incised at apex (Fig. 16).

Metaventrite transverse, ca. 1.2 times wider than long, with discrimen (metasternal suture) not quite attaining to mesosternal posterior margin (Fig. 17).

Elytra moderately long, ca. 3.1 times longer than wide at humeri, parallel-sided; with three stout, almost equally developed primary costae, only sutural costa noticeably weaker in distal half; interstices with even rows of irregular subquadrate cells; pubescence dense, short and decumbent (Fig. 16).

Legs relatively robust; hind coxae short, widely separated; trochanters elongate, pro- and mesotrochanters oval, metatrochanters triangular, with rounded outer angle; femoris and tibiae straight, subequal in length (Figs 16, 17).

Length: $8.2 \mathrm{~mm}$. Width at humeri: $2.6 \mathrm{~mm}$.

Male. Similar to female, but distinctly more narrow, antennae considerably longer, attaining to elytral four fifths, with short erect pubescence; mesotrochanters with more pronounced outer angles (Fig. 12).

DISTRIBUTION. Southern Russia (env. Eisk and Guzeripl in Krasnodar Kraj), Abkhasia (Sukhum), western Georgia (Bakuriani, Batumi) (Map 1).

Figs 12-15. General view and aedeagus of Benibotarus longicornis, adult male: 12-13 - general view; 14-15 — aedeagus; 12 dorsally; $13-14$ - ventrally; 15 - laterally. Scale: $0.5 \mathrm{~mm}$.

Рис. 12-15. Общий вид и эдеагус Benibotarus longicornis, имаго, самец: 12-13 - общий вид; 14-15 — эдеагус; 12 — сверху; 1314 - снизу; 15 - сбоку. Масштабная линейка: 0,5 мм. 


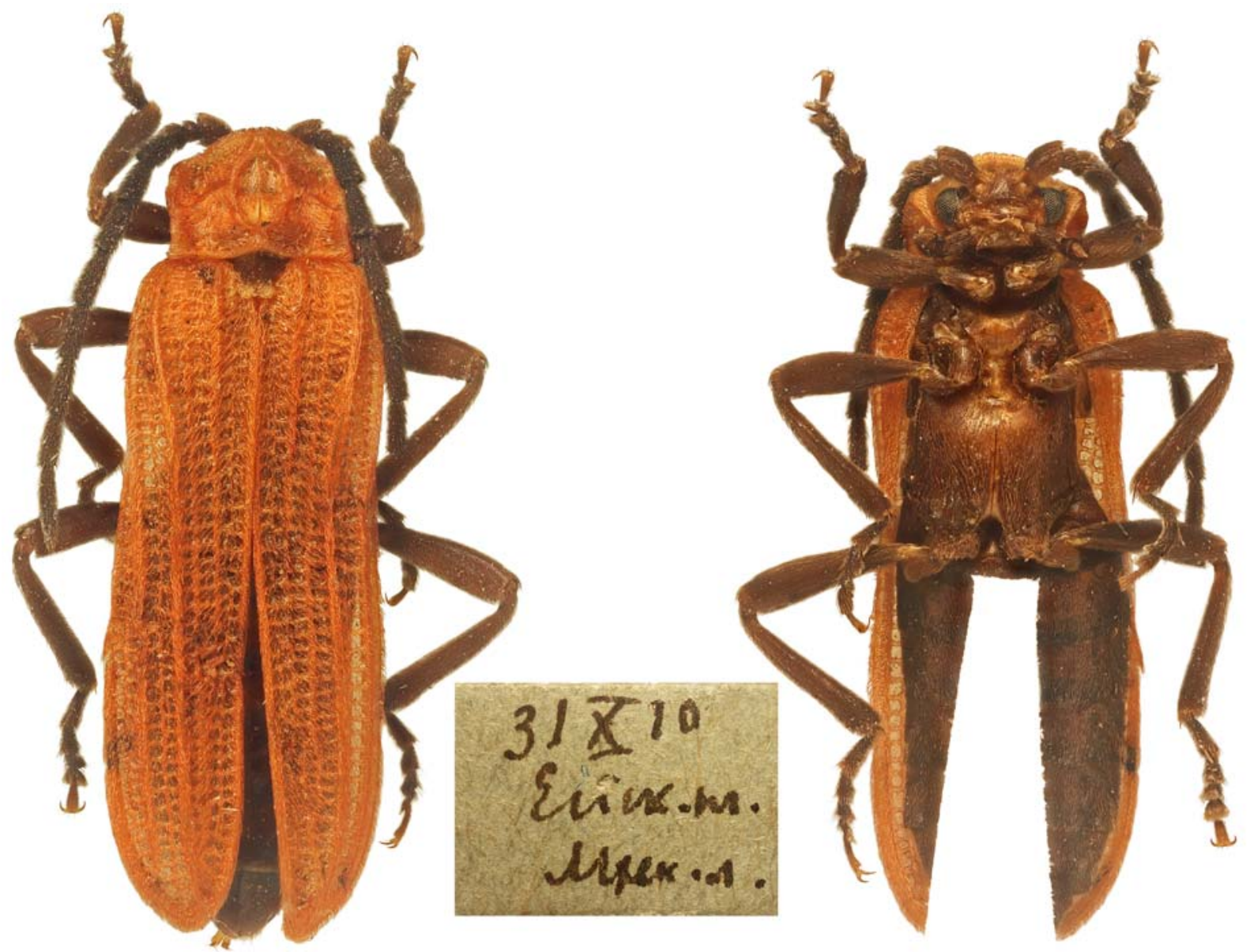

Figs 16-18. General view and label of Benibotarus longicornis, adult female: $16-17$ - general view; 18 - label; 16 - dorsally; 17 ventrally.

Рис. 16-18. Общий вид и этикетка Benibotarus longicornis, имаго, самка: 16-17 - общий вид; 18 — этикетка; 16 - сверху; 17 снизу.

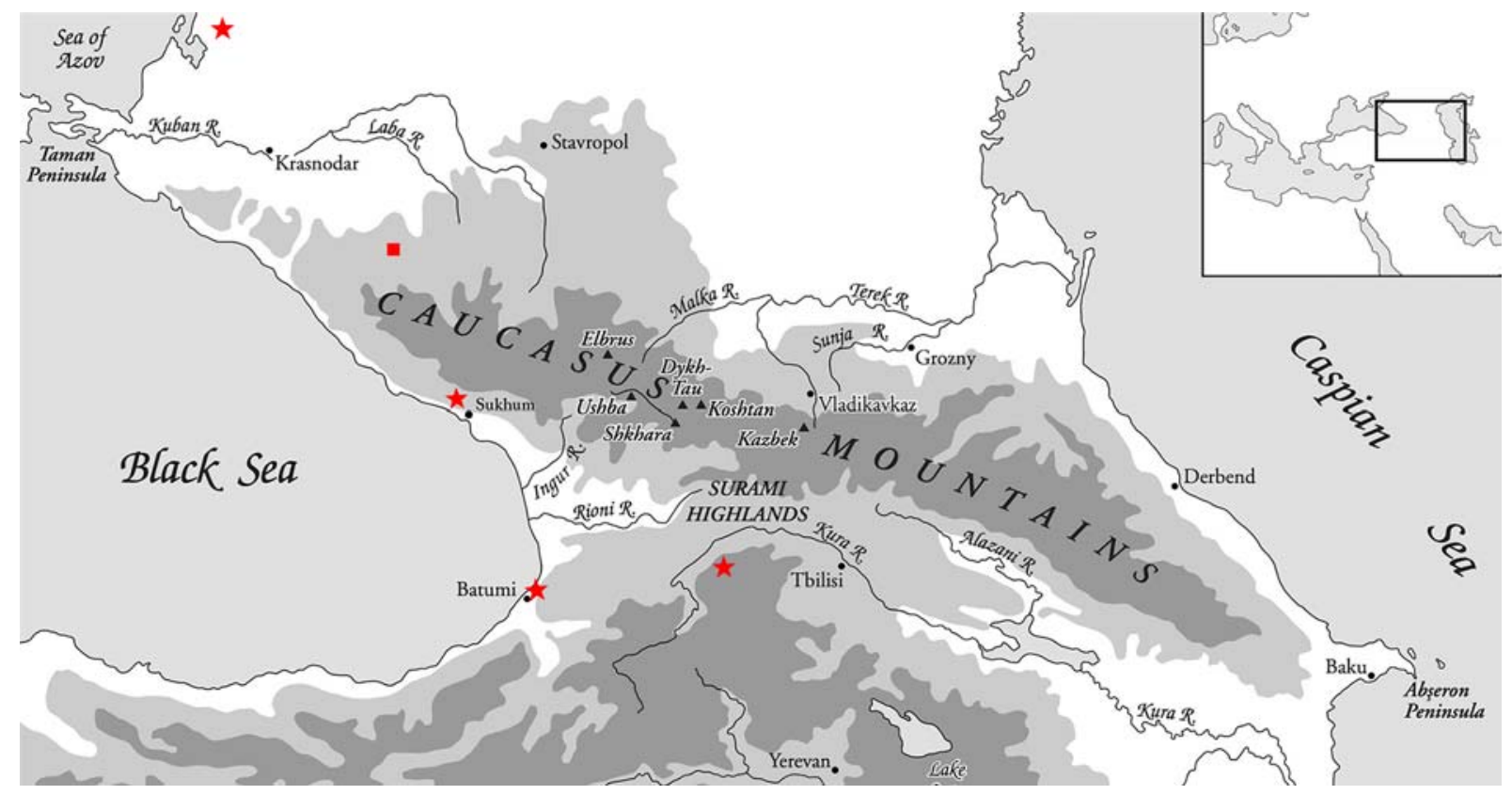

Map 1. Distribution of Benibotarus longicornis: $\star$ - adults; $\mathbf{\square}$ - larvae.

Карта 1. Распространение Benibotarus longicornis: $\star$ имаго; - - личинки. 


\section{Discussion}

Despite the fact that only four specimens of Benibotarus longicornis have so far been known, with the most recent collected ninety years ago, finding its larvae in the Caucasus Nature Reserve gives evidence that it has actually survived. On the other hand, it seems obvious that it is just about time to include this beautiful net-winged beetle in the Red Book of the Russian Federation and give it additional protection to increase its chances to be around at least within the boundaries of the Caucasus Nature Reserve.

Acknowledgements. It is our pleasant duty to express gratitude to Dr. Aleksej Gusakov (ZMMU) and Dr. Boris Korotyaev (ZIN) through whose courtesy we were able to study the unique adult Benibotarus specimens from the Lycidae collections under their care.

Competing interests. The authors declare no competing interests.

\section{References}

Barovskij V.V. 1930. Description d'une nouvelle espèce du genre Pyropterus Mulsant (Coleoptera, Lycidae) provenant de la Transcaucasie // Comptes Rendus de l'Académie des Sciences de l'URSS (1930). P.615-616.

Barovskij V.V. 1931. Beetles of the family Lycidae // Opredeliteli po faune SSSR. Issue 3. Leningrad: AN SSSR. 29 p. [In Russian]
Bocak L., Bocakova M. 1987. Notes on the taxonomy of some European species of the family Lycidae (Coleoptera) // Acta Entomologica Bohemoslovaca. Vol.84. P.111-121.

Bocakova M., Bocak L. 2007. Lycidae // Löbl I., Smetana A. (eds.). Catalogue of Palaearctic Coleoptera. Vol. 4. Stenstrup, Apollo Books. P.211-224.

Jacobson G. 1911. [Cantharididae] // Zhuki Rossii i Zapadnoi Evropy. Rukovodstvo po opredeleniyu zhukov. Vyp.9. St.Petersburg: A.F. Devrien. P.661-687 [in Russian].

Kazantsev S.V. 1990. Two new subgenera and a new species of lycids (Coleoptera) of the genus Dictyoptera from East Asia // Vestnik Zooogii. Vol.1. P.10-15 [in Russian, with English summary].

Kazantsev S.V. 2004. Phylogeny of the tribe Erotini (Coleoptera, Lycidae), with descriptions of new taxa // Zootaxa. Vol.496. P.1-48. https://doi.org/10.11646/zootaxa.496.1.1.

Kazantsev S.V. 2011. An annotated checklist of Cantharoidea (Coleoptera) of Russia and adjacent territories // Russian Entomological Journal. Vol.20. No.4. P.387-410.

Kazantsev S.V. 2012. A review of Erotinae and Dictyopterinae (Lycidae, Coleoptera), with description of new taxa and a note on biogeography of the subfamilies // Russian Entomological Journal. Vol.21. No.4. P.395-414.

Kazantsev S.V., Nikitsky N.B. 2011. Larvae of net-winged beetles (Lycidae, Coleoptera) of the European part of Russia and the Caucasus // Caucasian Entomological Bulletin. Vol.7. No.2. P.129-134.

Kleine R. 1942. Bestimmungstabelle der Lycidae // Bestimmungstabellen der Europäischen Coleopteren. 123. Troppau: E. Reitter. $90 \mathrm{~S}$.

Reiche M.L. 1878. Descriptions de deux nouvelles espèces de Coléoptères de la famille de Lycides // Annales de la Société entomologique de France. Vol.8. No.5. P.XXVII-XXVIII. 